\title{
Memori kolektif para kontributor berita wilayah pasca konflik dan peliputan keberagaman
}

\author{
Riris Loisa ${ }^{1}$, Gregorius Genep Sukendro ${ }^{2}$, Muhammad Gafar Yoedtadi \\ Lusia Savitri ${ }^{4}$, Roswita Oktavianti ${ }^{5}$ \\ $1,2,3,4,5$ Universitas Tarumanagara, Jakarta, Indonesia
}

\begin{abstract}
ABSTRAK
Pemberitaan keberagaman di dalam media konvergen belum banyak dijadikan kajian akademik. Artikel ini, bertujuan untuk membahas tentang pertimbangan para kontributor berita dari wilayah pasca konflik menjalankan tugasnya ketika meliput berita keberagaman untuk diberitakan di dalam media konvergen. Artikel ini merupakan luaran penelitian yang dilakukan dari perspektif teori normatif, dengan metode studi kasus mix-method. Penelitian dilakukan 2 (dua) tahap, tahap pertama berupa analisis isi terhadap beritaberita keberagaman di dalam akun resmi video share YouTube dari 2 (dua) media berita yang paling banyak diakses di Indonesia pada tahun 2018 versi Alexa.com, dilanjutkan dengan wawancara mendalam dengan para jurnalis kontributor media konvergen di wilayah pasca konflik, Ambon dan Aceh. Hasil penelitian memperlihatkan bahwa berdasarkan analisis isi, berita mengenai keberagaman wilayah pasca konflik di akun resmi YouTube dari kedua media yang diteliti pada tahun 2018 sangat rendah. Sementara dari wawancara mendalam, disimpulkan bahwa salah satu faktor yang melatarbelakangi rendahnya pemberitaan keberagaman tersebut adalah kehati-hatian para jurnalis pasca konflik dalam meliput peristiwa keberagaman dikarenakan memori kolektif traumatis akan dampak konflik dan pemberitaan konflik. Memori kolektif traumatik yang membuahkan kehati-hatian para kontributor di wilayah pasca konflik, patut menjadi pembelajaran bagi para kontributor berita di wilayah lain dalam memberitakan isu keberagaman, agar terhindar dari pengalaman traumatik yang dapat muncul sebagai dampak dari pemberitaan.
\end{abstract}

Kata-kata Kunci: Keberagaman; kontributor berita; media konvergen; memori kolektif; pasca konflik

\section{Collective memory of news contributors in post conflict area and of diversity coverage}

\begin{abstract}
Diversity coverage in convergent media has not been widely used as an academic study. This article, aims to discusses the consideration of news contributors from post-conflict areas in carrying out their duties when covering diversity news to be reported in convergent media. This article is the outcome of a study conducted from a normative theory perspective, using a study case mixed-method. The research was conducted in 2 (two) stages; the first stage was a content analysis of diversity news in the official YouTube video share accounts of the 2 (two) most accessed news media in Indonesia in 2018 according to Alexa.com, followed by in-depth interviews with journalists contributing to convergent media in post-conflict areas, Ambon and Aceh. The results show that based on content analysis, news about the diversity of post-conflict areas on the official YouTube account of the two media studied in 2018 was very low. Meanwhile, from in-depth interviews, it was concluded that one of the factors behind the low reporting of diversity was the caution of post-conflict journalists in reporting diversity events due to traumatic collective memory of the impact of conflict and conflict reporting. The traumatic collective memory that has resulted in the caution of contributors in postconflict areas should be a lesson for news contributors in any other areas in reporting on diversity issues in avoiding traumatic experiences that can arise from the news.
\end{abstract}

Keywords: Diversity; news contributor; convergent media; collective memory; post-conflict

Korespondensi: Dr. Riris Loisa, M.Si. Universitas Tarumanagara. Jl. Letjen S. Parman no. 1, Jakarta Barat 11440.Email: riris1@fikom.untar.ac.id 


\section{PENDAHULUAN}

Perkembangan media konvergen di Indonesia telah melahirkan berbagai kajian, misalnya tentang media konvergen dalam kaitannya dengan difusi inovasi (Resmadi \& Yuliar, 2014), pengelolaan sumber daya manusia (Prastya, 2017), dan pengelolaan redaksi (Pratopo \& Kusajibrata, 2018). Namun demikian, pemberitaan keberagaman di dalam media konvergen belum banyak dijadikan kajian akademik, padahal keberagaman merupakan isu penting di Indonesia.

Sistem pers Indonesia memiliki kekhasan ideologi dan falsafah negara Indonesia yakni Pancasila dan budaya masyarakat Indonesia. Sistem pers Indonesia disebut Pers Pancasila, di manakebebasan pers Indonesiaadalahkebebasan pers yang bertanggungjawab berdasarkan nilainilai Pancasila (Ardianto, Komala \& Karlinah, 2015). Undang Undang Nomor 40 Tahun 1999 tentang Pers menyebut pers nasional memiliki fungsi sebagai media informasi, pendidikan, hiburan, dan kontrol sosial. Pers nasional memiliki peran dalam menegakkan nilai-nilai dasar demokrasi, mendorong terwujudnya supremasi hukum, dan Hak Asasi Manusia, serta menghormati kebinekaan. Dalam konteks ini, Pers Indonesia menerapkan Teori Tanggung jawab Sosial dalam pelaksanaan tugas dan tanggung jawabnya sebagai pilar demokrasi.

Namun kenyataannya, berdasarkan penelitian yang dilakukan oleh Aliansi Jurnalis Independen (AJI), media massa justru kerap mengedepankan sensasi dalam pemberitaan dibandingkan pemersatu. Hal ini antara lain bisa dilihat ketika memberitakan konflik sosial. AJI bahkan mengimbau agar media online memperhatikan etika jurnalistik, terutama terkait persoalan Suku Agama Ras Antar Golongan (SARA), dan meminta media tidak menjadi provokator meluasnya konflik dengan pemberitaannya (Margianto \& Syaefullah, 2012).

Hakikatnya industri media bertugas menghibur, menginformasikan khalayak, menciptakan keuntungan bagi pemilik dan pemegang sahamnya. Namun di sisi lain, jurnalis perlu menyeimbangkan keuntungan dan tanggung jawab sosial (Baran, 2012). Jurnalis perlu memahami bahwa informasi yang diberitakan akan diterima dan tersimpan dalam ingatan/memori khalayak.

Para ahli studi ingatan (memory study) menekankan pentingnya media dalam membentuk ingatan kolektif: "Budaya dan ingatan individu terus-menerus dihasilkan melalui, dan dimediasi oleh, teknologi ingatan". Dalam hal ini, jurnalis merupakan agen memori kolektif (Gavilanes, Mollgaard, Tsvetkova \& Yasseri, 2017). Memori kolektif dipahami sebagai memori individu bersama. Seseorang tidak dilahirkan dengan ingatan "sosial" atau "kolektif", tetapi mereka mulai memahami ingatan-ingatan itu dan belajar untuk mengekspresikan secara efektif dan mengkomunikasikan pemahaman tentang dunia dalam ingatan mereka dengan berinteraksi secara sosial dengan orang lain (Golden, 2010).

Media massa sebagai ruang publik menjadi semakin luas dan berkembang dengan kehadiran media online dan media konvergen. Internet memiliki dampak kuat pada memori dan proses mengingat dan melupakan (Gavilanes, Mollgaard, Tsvetkova \& Yasseri, 2017).

Hal ini karena pesan media tidak hanya bersifat informatif dan persuasif, tetapi juga kohersif. Bentuk yang terkenal dari penyampaian dengan cara seperti ini adalah agitasi dengan penekanan-penekanan yang menimbulkan tekanan batin dan ketakutan di antara sesamanya dan pada kalangan publik (Nurhadi, 2017).

Indonesia masih memiliki pekerjaan rumah terkait keberagaman. Cara pandang media Indonesia tentang isu-isu keberagaman masih berbeda-beda. Beberapa persoalan akut yang belum bisa dipecahkan adalah tentang kepemilikan media yang rata-rata masih didominasi para politisi, kualitas konten siaran yang buruk dan cenderung mementingkan rating dan share (Kompas, 2019).

Konvensi 2005 berupaya memastikan terciptanya keberagaman media dilihat dari indikator keragaman konten, kepemilikan media, kemerdekaan media, demografi media, aksesibilitas media, transparansi media, hingga keberadaan data. Namun selama ini, banyak media masih cenderung memaknai keberagaman media dalam kacamata yang sempit, sematamata soal keragaman etnis, suku, dan agama yang ada di Indonesia. Oleh karena itu, Indonesia tengah meratifikasi Konvensi 2005 melalui Peraturan Presiden Nomor 78 Tahun 2011 (Kompas, 2019).

Berangkat dari pemaparan di atas, artikel ini akan memaparkan penelitian yang didasari perumusan masalah: bagaimana kontributor berita dari wilayah pasca konflik menjalankan tugasnya dalam meliput isu keberagaman untuk media konvergen.

Artikel ini bertujuan untuk menggambarkan memori kolektif para kontributor di wilayah pasca konflik serta bagaimana memori kolektif tersebut ikut berperan ketika para kontributor berita ini melakukan peliputan mengenai keberagaman.

Perspektif teori normatif memuat gagasan tentang bagaimana media seharusnya berperan. Penelitian ini berangkat dari perspektif teori normatif, yaitu teori tanggung jawab sosial (McQuail, 2011). Melalui teori ini McQuail 
menekankan peran penting pers dalam melindungi kepentingan masyarakat, dengan didasari beberapa prinsip utama antara lain: (a) media harus menerima dan memenuhi kewajiban tertentu kepada masyarakat; (b) kewajiban-kewajiban tersebut menyangkut keinformasian dengan standar kebenaran, akurasi, objektivitas dan keseimbangan; (c) media bebas dalam melaksanakan tugasnya; (d) media bersifat pluralistis dan merefleksikan kebinekaan masyarakat, memberikan kesempatan yang sama untuk mengekspresikan berbagai sudut pandang serta memberikan hak jawab; (e) media harus menghindari diri dari setiap upaya yang menjurus kepada tindak kejahatan, kekerasan, merusak tatanan sosial, atau menyakiti kelompok-kelompok minoritas; (f) masyarakat dan publik memiliki hak untuk menuntut standar kinerja yang tinggi dari pers, dan karenanya intervensi dibenarkan mengingat media massa merupakan public good wartawan dan kalangan profesional bertanggung jawab terhadap masyarakat, pihak majikan, serta pasar (Syam, 2006).

Di dalam era media konvergen seperti saat ini, para pelaku industri media memanfaatkan situs internet untuk berbagi video seperti youtube.com (Rimscha, 2016). Melalui situs berbagi video seperti ini, media dapat menjangkau pasar yang lebih luas (Grant \& Wilkinson, 2009). Keberadaan media konvergen telah menarik perhatian para akademisi dengan beragam fokus. Garcia-Aviles dan rekanrekannya, misalnya melakukan penelitian dengan penekanan pada aspek organisasi, alur kerja serta pengelolaan ruang berita media konvergen (Aviles, Kaltenbrunner \& Meier, 2014), Larrondo dan rekan-rekannya membahas media konvergen dalam kaitannya dengan sumber daya manusia sebagai anggota organisasi media (Larrondo, Domingo, Erdal, Masip \& Bulck, 2016). Penelitian ini berfokus pada para jurnalis sebagai kontributor berita pada media konvergen, khususnya di dalam peliputan keberagaman.

Memori kolektif merupakan terminologi yang cukup banyak mendapat perhatian di dalam penelitian akademik dan telah didefinisikan dalam berbagai perspektif antara lain sosiologi, psikologi dan antropologi. Pemikiran sosiologis tentang memori kolektif dapat ditelusuri dari karya Emile Durkheim dan Maurice Halbwaschs, yang berfokus pada proses di mana masa lalu direkonstruksi di masa sekarang, untuk melayani kebutuhan dan keinginan di saat ini. Walaupun pada mulanya kajian mengenai memori kolektif berpusat pada masa lalu yang heroik, tetapi kemudian banyak berkembang dengan memberi perhatian pada masa lalu yang sulit, berupa episode-episode yang membangkitkan rasa malu, penyesalan, perselisihan, traumatis, dan sebagainya, yang merupakan ancaman terhadap identitas bersama (Simko \& Simko, 2019).

Keberagaman merupakan kondisi dimana perbedaan dapat diterima, diikuti dengan perilaku menghargai dan menghormati perbedaan tersebut (Setyowati, 2015). Jika dikaitkan dalam kebijakan media, keberagaman atau diversity kerap diartikan sebagai "pluralitas informasi" dan "keberagaman suara". Kedua konsep tersebut menggambarkan dan membangun klaim normatif tentang berbagai model dan bentuk komersial dari konten yang harus ditemukan dalam media. Berita merupakan informasi yang dapat diverifikasi untuk kepentingan umum, memenuhi standar profesi dan etika (Ireton, Posetti \& Berger, 2018). Dengan demikian pemberitaan mengenai keberagaman merupakan informasi mengenai perbedaan anggota masyarakat, yang dilakukan melalui standar etika dan profesi jurnalis, dalam konteks penelitian ini, adalah para kontributor media konvergen.

\section{METODE PENELITIAN}

Penelitian pada artikel ini dilaksanakan dengan metode studi kasus mix-method. Studi kasus digunakan sebagai metode dan diterapkan melalui gabungan dari dua pendekatan kuantitatif dan pendekatan kualitatif. Metode studi kasus berupaya untuk menginvestigasi dan memahami kompleksitas aktivitas sosial yang merupakan perwakilan dari maknamakna yang dibawa oleh individu-individu aktor sosial pada setting dunia nyata. Studi kasus mengasumsikan bahwa realitas sosial diciptakan melalui interaksi sosial (Yin, 2014).

Studi kasus ini terintegrasi dengan sangat baik dengan mix-method yang mencari pemahaman yang lebih lengkap melalui integrasi dua pendekatan penelitian. Studi kasus yang diterapkan melalui pendekatan kuantitatif pada penelitian ini dilakukan dengan analisis isi pemberitaan-pemberitaan keberagaman yang ada di akun resmi YouTube dari dua media konvergen yang terpilih sebagai media berita yang paling banyak diakses pada tahun 2018. Sementara untuk penerapan studi kasus melalui pendekatan kualitatif dilakukan dengan wawancara mendalam kepada kontributorkontributor dari media konvergen tersebut, terutama yang ada di wilayah pasca konflik yaitu Ambon dan Aceh. 
Objek penelitian dalam artikel ini adalah peliputan berita keberagaman di wilayah pasca konflik untuk pemberitaan di media konvergen, dengan subjek penelitiannya adalah kontributorkontributor dari media konvergen tersebut di wilayah pasca konflik, terutama Ambon dan Aceh. Media konvergen yang menjadi objek merupakan dua media berita yang mempunyai basis pemberitaan di televisi dan sesuai dengan perkembangan era digital, mengembangkan sayap dengan merambah media konvergen terutama YouTube. Kedua media berita ini menempati peringkat teratas pada tahun 2018 menurut Alexa.com sebagai media konvergen yang paling banyak diakses di Indonesia.

Waktu pelaksanaan penelitian dibagi menjadi dua, yaitu waktu pelaksanaan analisis isi kemudian pelaksanaan wawancara mendalam. Analisis isi dilakukan untuk mengetahui isi media (Trilling \& Jonkman, 2018). Di dalam penelitian isi media yang dianalisis adalah mengenai pemberitaan keberagaman di 2 media konvergen yang diamati, antara lain untuk mengetahui jumlah pemberitaan keberagaman, unsur-unsur pemberitaan seperti siapa yang menjadi narasumber utama berita, apa saja topik keberagamannya, dsb. Data dikumpulkan mengacu pada instrumen yang dibangun berdasarkan studi literatur (Schulz, Woud \& Westhof, 2020), dalam bentuk kategori-kategori yang disesuaikan dengan tujuan penelitian (Benedictis, Johnson, Roberts \& Spiby, 2019).

Analisis isi dilaksanakan pada awal tahun 2019 dengan memperhatikan berita-berita keberagaman sepanjang tahun 2018. Setelah mendapatkan hasil dari analisis isi, dilaksanakan wawancara mendalam ke Ambon dan Aceh pada pertengahan 2019, dan penyelesaian penelitian dilaksanakan dari bulan Agustus sampai dengan Oktober 2019.

Pengumpulan data mengenai pemberitaan keberagaman di media konvergen berupa teks berita audio visual diunduh dari akun resmi YouTube kedua media konvergen yang menjadi obyek penelitian. Sebagai data yang digunakan untuk analisis isi, teks berita audio visual tersebut dipilih dan diobservasi berdasarkan pemberitaan dengan tema keberagaman sepanjang tahun 2018. Setelah mendapatkan data mengenai pemberitaan keberagaman di wilayah pasca konflik dari analisis isi, maka data tersebut dijadikan dasar untuk mengumpulkan data kualitatif yaitu dari wawancara mendalam terhadap para pelaku peliputan berita tersebut di Ambon dan Aceh, sebagai wilayah pasca konflik.

Analisis data dalam penelitian ini dilakukan dengan melakukan interpretasi hasil olah data analisis isi dan hasil wawancara mendalam melalui proses koding/kategorisasi. Hasil olah data analisis isi yang menjadi dasar untuk wawancara mendalam kemudian menjadi data kualitatif hasil wawancara.

Data kualitatif adalah data yang berbentuk kata-kata, bukan dalam bentuk angka. Data kualitatif diperoleh melalui berbagai macam teknik pengumpulan data misalnya wawancara, analisis dokumen, diskusi terfokus, atau observasi yang telah dituangkan dalam catatan lapangan (transkrip). Bentuk lain data kualitatif adalah gambar yang diperoleh melalui pemotretan atau rekaman video. Dalam hal ini data kualitatif telah dituangkan dalam bentuk transkrip. Analisis data kualitatif dilakukan dengan mengorganisasikan data, menjabarkannya ke dalam unit-unit, melakukan sintesis, menyusun ke dalam pola, memilih mana yang penting dan mana yang akan dikaji sehingga dapat dibuat suatu kesimpulan untuk disampaikan kepada orang lain.

Aktivitas dalam analisis data kualitatif dilakukan secara interaktif dan berlangsung secara terus-menerus sampai tuntas, sehingga datanya jenuh. Ukuran kejenuhan data ditandai dengan tidak diperolehnya lagi data atau informasi baru. Aktivitas dalam analisis meliputi reduksi data (data reduction), penyajian data (data display), serta penarikan kesimpulan dan verifikasi (conclusion drawing/verification) (Milles, Huberman \& Saldana, 2014).

Dalam penelitian ini, untuk mendapatkan data yang valid maka perlu juga dilakukan triangulasi. Triangulasi merupakan pengujian keabsahan data yang diperoleh dari berbagai sumber, berbagai metode, dan berbagai waktu. Oleh karenanya terdapat teknik pengujian keabsahan data melalui triangulasi sumber, triangulasi metode, dan triangulasi waktu. Pada penelitian ini dilakukan triangulasi sumber dan triangulasi metode. Triangulasi sumber dilakukan dengan mengecek data yang diperoleh kepada beberapa sumber. Kemudian triangulasi metode yang dilakukan adalah dengan mengecek data hasil wawancara dengan data hasil observasi dan hasil analisis dokumen atau literatur utama. 
Kategorisasi dalam analisis isi merupakan instrumen pengumpul data. Fungsinya sama dengan kuesioner dalam survei. Supaya objektif maka kategorisasi harus dijaga reliabilitasnya. Oleh karena itu uji reliabilitas dilakukan untuk melihat apakah alat ukur dapat dipercaya menghasilkan temuan yang sama, ketika dilakukan oleh orang yang berbeda. Dalam penelitian ini, uji reliabilitas digunakan melalui kategorisasidalaminstrumenyangmemilikinilai reliabilitas yang tinggi dimana kemungkinan terjadinya beda penafsiran antar para coder sangat rendah. Unit analisis ini didasarkan pada kategorisasi yang telah ditentukan seperti jenis berita, topik berita, narasumber yang digunakan, pesan keberagaman, serta konten dan jenis iklan yang menyertai berita tersebut, yang tertera jelas dalam suatu teks berita audio visual yang dianalisis. Antara para penilai coder secara teoritis akan menghasilkan temuan yang sama, karena mereka hanya perlu mencatat dan menghitung jumlah masing-masing kategorisasi yang tertera dalam teks berita itu.

\section{HASIL DAN PEMBAHASAN}

Di dalam penelitian ini dua media konvergen yang menjadi objek penelitian adalah media berita, meskipun demikian keduanya memiliki awal yang berbeda, media pertama bermula dari program berita di televisi, sementara media kedua berawal dari media berita online yang kemudian diikuti media berita penyiaran.

Selain media penyiaran, keduanya memiliki akun resmi di dalam laman situs YouTube, yang muncul dengan iklan. Di samping itu kedua media berita memiliki aplikasi media sosial berupa akun Facebook, Twitter dan Instagram. Penggunaan berbagai platform untuk menunjang program siaran sangatlah bermanfaat, selain gratis, pengelolaan dengan baik akan menjadikan target yang ingin dicapai akan semakin lebih mudah (Vebrynda, Maryani \& Abdullah, 2017).

Tabel 1 memperlihatkan jumlah total berita keberagaman yang berhasil dikumpulkan di kedua media konvergen sepanjang tahun 2018 adalah masing-masing sebanyak 65 dan 62 berita, dengan demikian terdapat total 127 berita keberagaman dari kedua media konvergen di dalam akun Youtube yang dianalisis.

Keberagaman adalah isu yang kritis, terutama di dalam masyarakat majemuk seperti Indonesia. Kritis karena keberagaman melibatkan orang-orang yang memiliki latar belakang berbeda dalam hal cara berpikir, nilainilai yang dianut, dan dalam hal cara untuk memahami realitas (Loisa, Susanto \& Junaidi, 2019). Berita keberagaman yang terkumpul sepanjang tahun 2018 dari akun YouTube kedua media berita tidak terpaut jauh, namun jumlah pengguna internet yang melihat mengakses kedua akun terpaut jauh, yaitu 2.368.118 dan 4.497.724 dengan demikian 127 berita yang dianalisis dilihat oleh 6.865 .842 pengguna internet. Perbedaan yang cukup tajam juga terlihat dalam hal komentar dari para pengakses berita yaitu 2.015 komentar dan 19.400 komentar. Berdasarkan lokasi pemberitaan keberagaman sepanjang tahun 2018 di kedua media diperoleh data sebagai berikut, pada tabel 2.

Dari hasil analisis isi, terlihat bahwa berita keberagaman dari 2 wilayah pasca konflik sangat rendah: berita keberagaman mengenai Aceh hanya terdapat 3 berita, dengan rincian 2 berita di media 1 dan 1 berita di media 2 . Sedangkan berita keberagaman dari Ambon hanya ada 2 berita di media 1 . Hal ini cukup mengejutkan mengingat bahwa kedua kota tersebut pernah menjadi pusat pemberitaan berbagai media massa selama kurun waktu yang cukup panjang.

Di samping itu, dari hasil analisis isi muncul beberapa kategori isu keberagaman, dimana persentase tertinggi adalah pada pemberitaan mengenai kebudayaan, seperti mengenai adat, suku, dsb. Tidak mengherankan jika budaya menjadi kategori dengan persentase tertinggi. Budaya memberikan nilai kehidupan dalam diri manusia, karena melalui budaya yang tercipta maka keberadaan manusia dalam menciptakan suatu peradaban dapat diakui (Marta \& Rieuwpassa, 2018).

\begin{tabular}{lll}
$\begin{array}{c}\text { Tabel } 1 \text { Perbandingan Pemberitaan Keberagaman, } \\
\text { Pengakses, dan Komentar Pengakses pada } \\
\text { Dua Akun Resmi Media Berita dalam } \\
\text { Situs YouTube }\end{array}$ \\
\hline Kategori & Media 1 & Media 2 \\
\hline Total Berita & 65 & 62 \\
Total Pengakses & $2,368,118$ & $4,497,724$ \\
Total Komentar & 2,015 & 19,400 \\
\hline
\end{tabular}

Sumber: Hasil Penelitian, 2019 
Tabel 2 Lokasi Pemberitaan Keberagaman Pada Dua Akun Resmi Media Berita dalam Situs YouTube Pada Tahun 2018

\begin{tabular}{|c|c|c|c|}
\hline No. & Lokasi & Media 1 & Media 2 \\
\hline 1 & Ambon & 2 & 0 \\
\hline 2 & Banda Aceh & 2 & 1 \\
\hline 3 & Bandung & 1 & 2 \\
\hline 4 & Bantul & 0 & 1 \\
\hline 5 & Banyuwangi & 1 & 1 \\
\hline 6 & Batam & 1 & 0 \\
\hline 7 & Batu & 0 & 1 \\
\hline 8 & Bekasi & 2 & 0 \\
\hline 9 & Bogor & 3 & 1 \\
\hline 10 & Bojonegoro & 1 & 1 \\
\hline 11 & Denpasar & 4 & 4 \\
\hline 12 & Garut & 1 & 0 \\
\hline 13 & Jakarta & 28 & 21 \\
\hline 14 & Jember & 1 & 1 \\
\hline 15 & Jepara & 1 & 0 \\
\hline 16 & Kenyam & 1 & 1 \\
\hline 17 & Kuningan & 0 & 1 \\
\hline 18 & Kupang & 1 & 0 \\
\hline 19 & Kuta & 0 & 1 \\
\hline 20 & Lombok & 0 & 1 \\
\hline 21 & Lumajang & 1 & 1 \\
\hline 22 & Magelang & 1 & 0 \\
\hline 23 & Makassar & 0 & 1 \\
\hline 24 & Medan & 1 & 2 \\
\hline 25 & Mojokerto & 0 & 1 \\
\hline 26 & Ngawi & 1 & 0 \\
\hline 27 & Palangkaraya & 1 & 0 \\
\hline 28 & Pasuruan & 0 & 1 \\
\hline 29 & Probolinggo & 0 & 1 \\
\hline 30 & Purwakarta & 0 & 1 \\
\hline 31 & Semarang & 1 & 0 \\
\hline 32 & Sidoarjo & 2 & 0 \\
\hline 33 & Solo & 4 & 1 \\
\hline 34 & Sukoharjo & 1 & 0 \\
\hline 35 & Surabaya & 3 & 12 \\
\hline 36 & Tangerang & 2 & 0 \\
\hline 37 & Tasikmalaya & 1 & 0 \\
\hline 38 & Timika & 1 & 0 \\
\hline 39 & Wonosobo & 0 & 1 \\
\hline 40 & Yogyakarta & 1 & 0 \\
\hline
\end{tabular}

Sumber: Hasil Penelitian, 2019
Pada kedua media, rerata porsi berita mengenai kebudayaan porsi sebesar 41\%, pemberitaan kebudayaan pada media 1 mencapai sebesar 37\%, sementara di media kedua sebesar $45 \%$. Isu kedua tertinggi adalah pemberitaan tentang keagamaan, dengan rerata pemberitaannya pada kedua media sebesar $35 \%$, dengan rincian pemberitaan pada media 1 sebesar $40 \%$, sementara pada media 2 sebesar 29\%. Isu ketiga tertinggi adalah pada pemberitaan mengenai isu jender, dengan rerata nilai sebesar $9 \%$, dengan rincian $12 \%$ pada media 1 , dan $6 \%$ pada media 2 . Data tersebut tercermin dalam grambar 1 .

Selebihnya adalah pemberitaan mengenai Hak Asasi Manusia (HAM) dan isu lain-lain, masing-masing dengan rerata $8 \%$. Isu HAM pada media 1 sebesar $6 \%$, sedangkan pada media 2 sebesar 10\%. Isu lain-lain pada media 1 sebesar $5 \%$ dan pada media 2 sebesar 10\%. Gambaran rincian isu keberagaman yang diberitakan di media konvergen dirangkum dalam gambar 1. Rendahnya pemberitaan keberagaman di wilayah pasca konflik seperti Aceh dan Ambon, perlu penelusuran lebih lanjut.

Pada tanggal 24 Desember 2004, gempa dahsyat dan gelombang raksasa Tsunami menerjang Aceh. Bencana ini membawa duka mendalam tidak hanya bagi rakyat Aceh, tetapi juga bagi bangsa Indonesia. Bencana dapat melahirkan dampak dua sisi, sisi positif dan sisi negatif. Namun bencana (alam) harus senantiasa disiasati dengan positif untuk segera bangkit dan berbenah diri. Hal ini yang dilakukan oleh Tanah Rencong, Serambi Mekkah. Merunut ke belakang, asal-usul masyarakat Aceh adalah suku Batak/Karee yang membentuk kaum Lhee Reutoih. Pertemuan seperti Arab, Persia, Turki, Keling, Melayu Semenanjung, dan Bugis, membentuk kaum Tok Batee Sultan. Kaum percampuran dari Hindu dan Batak Karee membentuk group baru menjadi kaum Ja Sandang (Zainuddin, 1961).

Pasca Tsunami tahun 2005, Aceh lebih terbuka untuk semua orang, yang menyebabkan masuknya orang dari berbagai kalangan, berbagai pemahaman, dan dengan segala macam kegiatan kemanusiaan. Hal ini menandai era baru masyarkat Aceh. Seperti yang dituturkan oleh dua kontributor Aceh dari dua media konvergen yang menjadi objek penelitian.

Kontributor dari Aceh, sekaligus sebagai 


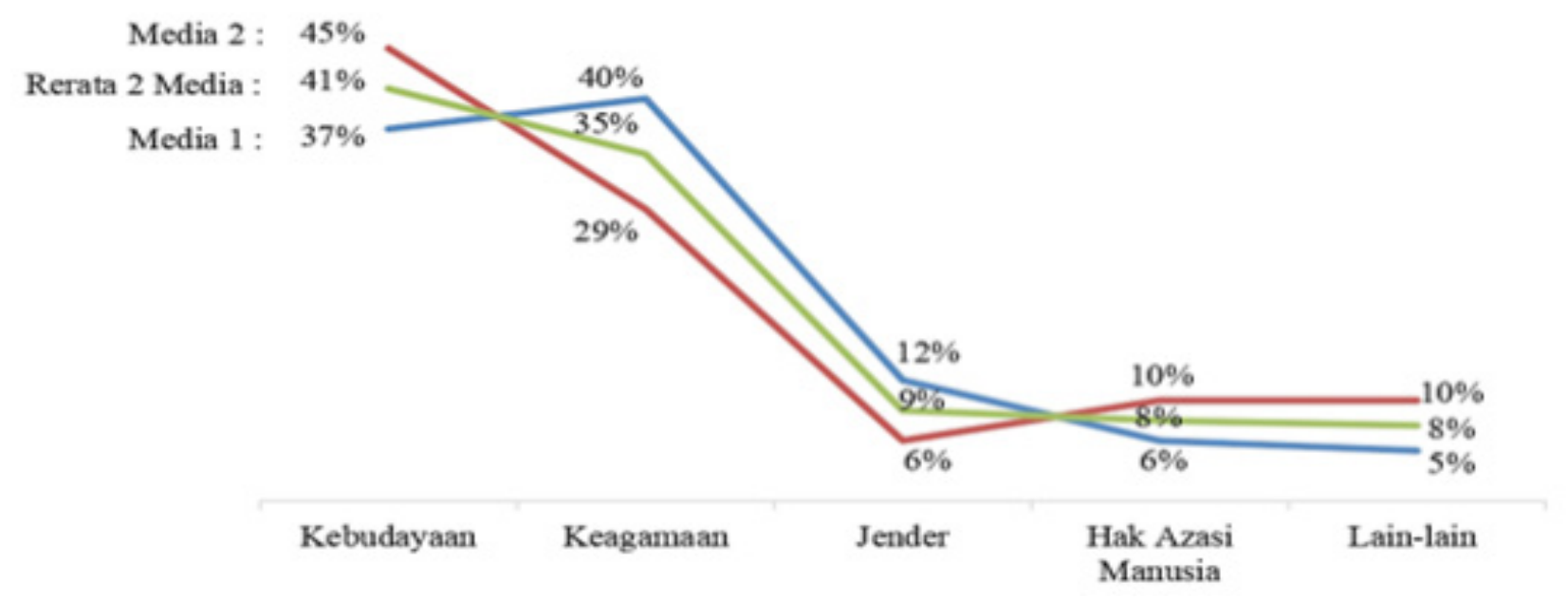

Sumber: Hasil Penelitian, 2019

\section{Grafik 1 Kategori Isu Keberagaman pada Dua Akun Resmi Media Berita dalam Situs YouTube Pada Tahun 2018}

narasumber pertama penelitian ini, melihat perbedaan masyarakat Aceh sebelum dan setelah Tsunami, seperti pernyataannya berikut ini:

"Masyarakat Aceh sebelum Tsunami itu beda banget. beda, cara berpikirnya kalau orang-orang di daerah berbeda, selain Banda Aceh agak sedikit majulah, ya, karena ibu kota provinsi. Di daerah kalau ada yang berbeda selalu dicurigai terutama dari segi agama, kalau bukan Islam tidak boleh. Setelah itu (Tsunami) sampai ke pelosok pun sekarang terbuka, siapa saja yang datang ke desa, misal tamu asing disambut dengan baik, jadi lebih terbuka."

Masih menurut narasumber ini, tahun 2005, 2006, 2007 adalah masa pemulihan, sembari memperbaiki fisik, daerah juga memperbaiki pikiran orang-orang bahwa terbuka itu lebih baik, berkenalan lebih jauh dengan orang itu, berserikat dengan orang lain itu lebih baik. Kondisi terbuka ini juga yang membawa angin perubahan pada kerja jurnalistik di Aceh. Kerjakerja jurnalistik tidak lagi mencekam, mulai dari peliputan, wawancara, investigasi menembus narasumber, dan narasumber menjadi lebih mudah menyampaikan informasi, tanpa lagi ada rasa takut dan curiga. Seperti dalam kredo "Sembilan Elemen Jurnalisme" dan "Blur" karya Bill Kovach \& Tom Rosenstiel: elemen kedua, bahwa loyalitas utama wartawan adalah kepada masyarakat, bukan pada perusahaan tempatnya bekerja, pembaca, atau pengiklan. Wartawan harus berpihak pada kepentingan umum. Elemen ketiga, esensi jurnalisme adalah verifikasi, memastikan bahwa data dan fakta yang digunakan sebagai dasar penulisan bukan fiksi, bukan khayalan, tetapi berdasarkan fakta dan pernyataan narasumber di lapangan.

Pasca 2005, peliputan fakta di lapangan mulai lebih nyaman. Seperti yang diungkapkan narasumber berikut, "Liputan pasca 2005 lebih nyaman, kalau sebelum itu tidak nyaman bukan karna keberagaman, tapi karna konflik bersenjata, jadi keberagamannya tidak terlihat di sana (Aceh)".

Kebebasan liputan berita di Aceh tidak mengalami hambatan dalam peliputan kasuskasus keberagaman, karena di Aceh masyarakat cenderung hidup dalam kesegaraman. Kesamaan dalam agama dan kebudayaan asli, maka kemungkinan gesekan yang mengarah pada konflik vertikal sangat minim. Namun kemencekaman liputan justru terjadi pada saat konflik senjata antara TNI dengan GAM (Gerakan Aceh Merdeka). Konflik senjata ini membawa dampak traumatis pada masyarakat Aceh, maupun bagi para kontributor berita, yang menjadi sangat hati-hati di dalam memberitakan pertanyaan bermuatan ketidak sepahaman atau perseteruan. Sehubungan dengan hal tersebut, narasumber kontributor Aceh ini menyatakan,

"Karena kalaupun ada narasumber aktivis mengatakan ketidak sepahamannya pasti dengan ungkapan yang sangat sangat halus, karena mereka juga berpikir bahwa ini kepentingan orang banyak ... mereka 
juga berpikir gitu, karena capek sekali masyarakat Aceh ini berseteru, jadi setelah 2005 bagaimana semua orang tanpa dikomando mulai berpikir bagaimana kita tenang sekarang, karena capek saja mengalami masa di 2004 itu sangat sangat susah hidup konflik itu, jadi semua orang ingin terbebas dari itu sekarang."

Dalam sebuah konflik terbuka, para pihak yang berkonflik dapat memanipulasi prasangka untuk mencapai tujuan politik (Putra \& Pitaloka, 2012). Konflik yang berkepanjangan dapat terus meningkatkan dan mempertahankan prasangka. Hal ini dialami masyarakat Aceh, sekaligus sangat berpengaruh dalam kerja jurnalistik. Kenyataan tersebut menjadi problematik mengingat bahwa tugas jurnalis yang utama adalah menjalankan profesi secara independen dengan mengikuti kaidah-kaidah jurnalistik.

Jurnalis tidak boleh memihak salah satu kelompok atau hanya menyuarakan pihak tertentu dan menafikan keberadaan pihak tertentu. Ia harus memiliki komitmen ketika bertugas untuk mencari berita dan menginformasikannya kepada pembaca atau publik sesuai standar teknis dan etika jurnalistik. Semua pihak memiliki hak yang sama atas akses informasi. Tidak hanya itu, landasan moral dan etika profesi sebagai pedoman operasional dalam menjaga kepercayaan publik dan menegakkan integritas serta profesionalisme juga tertuang dalam Kode Etik Jurnalistik (KEJ) (Laksono, Bachyul, Nugroho, Suwarjono, Saputra, Pramudya, Sudibyo \& Budhi, 2012).

Namun, adakalanya kontributor berita di daerah menghadapi problematika untuk menegakkan kode etik profesi ini. Hal tersebut antara lain mengemuka ketika para kontributor berhadapan dengan tuntutan dari redaksi di kantor pusat, untuk menulis berita lokal yang kontroversial. Hal ini tercermin dari pernyataan salah satu narasumber kontributor berita di Aceh berikut ini:

"Kalau soal peliputan, saya pribadi yang agak sering semacam bentrok sama kantor (Jakarta), kadang-kadang suka request ... cari satu aktivis yang kontra gitu, itu yang saya tidak pernah lakukan, ... kita tidak pernah adil dengan pendapat si aktivis yang kontra, pertama memang ga ada ... susah carinya aktivis yang vokal. Kalaupun ada satu dua ada mungkin, tapi mereka tidak menjadikan perbedaan yang dia punya itu sebagai satu hal yang tendensius. Jadi di sini kalau nulis berita landai-landai aja, cuman orang persepsinya berbeda, emang ga paham gitu, kita di sini memahami mereka (redaksi Jakarta). Ketika menyoal tentang pemahaman redaksi pusat dengan para kontributor di lapangan, khususnya dalam hal peliputan spesifik lokal".

Pemahaman liputan menjadi satu permasalahan tersendiri antara orang yang ada di dalam wilayah yang menjadi berita, dengan orang yang jauh dari tempat kejadian. Hal ini bahkan bisa terjadi di dalam tim redaksi, seperti penjelasan narasumber kontributor di Aceh berikut ini:

"Soal liputan saya belum pernah tuntas soal itu, selalu ada yang tidak saya cover ada request kantor (pusat) soal alasannya itu tadi, minta angel yang sayang kalo misal kita buat, ya ngga saya buat. Dan saya ngomong, saya jelaskan, tidak seperti itu, kan sudah kirim semacam lead, saya jelasin kalo itu tidak begini sebenernya, tidak ada justru yang merasa ngga setuju ... Redaktur saya anggap paham, walaupun mungkin agak kecewa, saya ngga tau juga. Sehingga dulu saya pernah, mas saya ga bisa nih. (Ditanya) Masa ngga bisa? TV sebelah ada masa kita ngga ada... Dan teman-teman di Jakarta, teman-teman jurnalis di kantor baru sadar kondisi itu ketika dia liputan di Aceh".

Berdasarkan kebijakan penugasan para kontributor daerah dan kebijakan redaksi pusat, dapat terlihat, bahwa meskipun secara historis pers Indonesia pada awalnya bersifat idealis, namun dalam perkembangan selanjutnya cenderung mengutamakan bisnis. Orientasi bisnis ini makin mendorong pers meninggalkan orientasi politik yang kritis (Hill, 1995) dan orientasi bisnis media menguat. Menurut Sukendro, pada kenyataannya publik tetap memiliki keinginan kuat untuk mendapatkan berita-berita yang kritis, seperti kasus pada rezim Orde Baru, munculnya Tabloid DeTIK, sebuah tabloid miskin iklan namun menyandarkan pemasukan dana dari pembeli sehingga isi beritanya sangat lugas, jelas, dan terverifikasi (Hidayat, 2000).

Bagi kontributor Aceh, memori kolektif 
traumatik menimbulkan menghasilkan suatu dampak positif, yaitu meningkatnya kesadaran akan pentingnya tetap memelihara idealisme dengan berpegang pada Kode Etik Jurnalistik, seperti disampaikan oleh narasumber tersebut, "Para jurnalis di Aceh pasca 2005 itu, sangat meningkat kesadarannya karena peranan aktif organisasi kewartawanan yang selalu mengedukasi para wartawan muda. Peran aktif organisasi pers AJI Aceh (Aliansi Jurnalis Independen), mengedukasi supaya tetap berpegang teguh pada kode etik jurnalistik".

Berbeda dari memori kolektif para jurnalis kontributor di Aceh, para kontributor di Ambon memiliki memori kolektif yang muncul dari konflik Kristen-Muslim di Ambon dan wilayah Maluku yang berlangsung dalam kurun waktu relatif lama. Pecah di tahun 1999 dan berakhir tahun 2002 dengan perjanjian damai Malino. Meski demikian hingga tahun 2011, konflik komunal dengan skala kecil dan lokal masih sering terjadi (Lindawati, 2011).

Begitu parahnya konflik agama di Ambon menjadi perhatian banyak peneliti sosial. Gerry van Klinken menggambarkan sebagai konflik paling mengerikan di Indonesia dilihat dari skala kematian dan kehancuran. Sementara Bohm melukiskan sebagai konflik yang paling kompleks dalam hal aktor yang terlibat, fase kekerasan dan motif - motif di balik tragedi tersebut (Qurtuby, 2016).

Salah satu faktor yang memperkeruh konflik agama di Ambon adalah media massa yang tidak objektif dalam membuat berita (Sudibyo, 2013). Hasil penelitian Sudibyo menunjukkan media massa di Ambon gagal mengkonstruksi fakta secara berimbang. Bias agama mewarnai pemberitaan konflik di Ambon. Pemberitaan konflik oleh media massa dapat membawa pengaruh pada dua hal. Pertama, pemberitaan media justru memperluas eskalasi konflik. Kedua, dapat membantu meredakan dan menyelesaikan konflik (Santosa, 2017).

Konflik agama menjadi trauma tersendiri bagi sebagian besar masyarakat Ambon, tak terkecuali para jurnalis di kota Ambon. Keinginan untuk menjaga perdamaian dan menghindari konflik kembali terulang tertanam dalam benak para jurnalis di Ambon. Mereka menyadari bahwa konflik sosial yang pernah terjadi di Ambon, menyengsarakan banyak pihak. Tak hanya dari kalangan Muslim, tapi juga kalangan Kristen. Ketiga kontributor yang menjadi narasumber penelitian ini memberikan jawaban seragam mengenai kesadaran diri untuk menjaga perdamaian di Ambon.

Narasumber kontributor berita di Ambon menjelaskan, bahwa pengalaman konflik merupakan suatu pembelajaran yang berharga. Pembelajaran tentang pentingnya demokrasi.

"Kami betul-betul ... belajar banyak dari itu pengalaman konflik dulu (tahun) 99 (1999).

Kami tidak menampikkan sebetulnya. Karena itu sesungguhnya menurut saya, saya patuh menghadirkan demokrasi begitu harus ... harus ada gitu ... itu prinsipnya gitu. Supaya biar ini lah, saya berharap itu stabil itu bisa terpenuhi gitu. Tapi lagi-lagi konflik itu kami ... menjadi referensi untuk kami terus ... sesuatu yang berharga sekali. Termasuk kami posisi ke narasumber, karena kami berpikir bicara verbal itu, itu masih berasa. Saya masih merasakan itu. Jangan sampai ter-frame nya disitu."

Poin positif berupa kesadaran diri untuk ikut menjaga perdamaian di Ambon, sayangnya tidak diikuti dengan langkah peliputan yang benar. Dalam membuat berita para kontributor memilih bingkai berita (frame) yang dianggap "aman" dengan mengambil angle aparat keamanan, antara lain polisi atau TNI. Aparat keamanan selalu menjadi narasumber utama dalam pemberitaan jurnalis di Ambon. Pernyataan aparat keamanan menjadi legitimasi bagi para jurnalis bahwa mereka telah memberitakan dengan netral, seperti yang dijelaskan oleh narasumber kontributor media konvergen di Ambon lainnya, "(Aparat) Paling netral. Karena, jujur saja secara verbalnya itu masih ada sih.. verbalnya masih berasa sampai sekarang, maka saya hati-hati. Karena situasi seperti itu masih terjadi sampai sekarang,"

Selain dinilai netral, wawancara terhadap apparat dilakukan untuk menghindari narasi yang bermuatan provokatif, seperti pernyataan narasumber berikut ini:

"Kenapa harus wawancara aparat pemerintah? Karena kita ini kan tinggal di Ambon, ya sama-sama tinggal di Ambon, cari makan sama-sama, ingin hidup lebih damai, harus wawancara pemerintah aparat. Karena kita sama-sama niatnya mau Ambon ini harus damai. Kalau seandainya kita wawancara masyarakat, masyarakat saja ya, bukan tokoh masyarakat, pasti 
ada bumbu-bumbu provokasi. Jadi, di narasi yang dibuat itu seakan-akan tuh provokasi”.

Jurnalis di Ambon menyadari bahwa aparat memiliki peran dalam menjaga perdamaian dan menghindari konflik agama kembali terulang. Penderitaan yang mereka rasakan selama konflik menyebabkan trauma mendalam. Para kontributor berita berkeyakinan bahwa media dapat berperan dalam meredam konflik di Ambon. Bagi para kontributor berita ini model jurnalisme damai (peace journalism) menjadi pegangan dalam memberitakan peristiwa berpotensi konflik. Namun disayangkan, keinginan untuk membuat berita yang "aman" dirumuskan secara sederhana dengan mengambil narasumber utama dari aparat keamanan.

Memilih aparat menjadi narasumber utama pemberitaan yang bermuatan konflik, sejalan dengan salah satu temuan penelitian tentang kecenderungan media untuk memilih aparat pemerintah sebagai narasumber utama dalam pemberitaan keberagaman. Penelitian tersebut menyimpulkan, bahwa dalam memberitakan isu-isu sensitif, media memilih aparat karena dinilai sebagai otoritas berwenang dan merupakan sumber resmi yang patut dipercayai, serta akurat (Loisa, Susanto, Junaidi \& Loekman, 2019).

Dibagian awal artikel ini telah dikemukakan bahwa dari perspektif teori normatif, media antara lain memiliki kewajiban keinformasian dengan standar kebenaran, akurasi, obyektivitas dan keseimbangan. Media seyogyanya bersifat pluralistis dan merefleksikan kebinekaan masyarakat, serta memberikan kesempatan yang sama kepada berbagai pihak untuk mengekspresikan berbagai sudut pandang (Syam, 2006).

Di satu sisi, memori kolektif traumatik menyebabkan para kontributor media konvergen dari wilayah pasca konflik ini membangun suatu standar yang tinggi dalam hal penerapan jurnalisme damai. Di sisi lain, hal ini sedikit banyak bisa mempengaruhi akurasi, obyektivitas dan keseimbangan di dalam menyajikan keberagaman sudut pandang. Para kontributor berita yang menjadi narasumber penelitian ini memperlihatkan, bahwa memori kolektif traumatik menyebabkan tarik menarik antara trauma akan dampak konflik dan kepentingan manajemen media untuk menyajikan berita termasuk yang bermuatan konflik. Bagi para kontributor berita di wilayah pasca konflik, memberikan kesempatan yang sama kepada berbagai pihak untuk mengekspresikan sudut pandangan yang berbeda mengenai isu keberagaman, merupakan hal yang problematik.

Pemaparan para kontributor media konvergen dari wilayah pasca konflik setidaknya memperlihatkan beberapa hal, seperti yang akan dikemukakan di dalam pembahasan di beberapa paragraf berikut ini.

Pertama, dalam melakukan tugas pemberitaan, para jurnalis ini membawa serta memori kolektif traumatis, berupa trauma dari konflik yang dialami masyarakat lokal di masa lampau. Sejalan dengan pemikiran Simko tentang keterkaitan memori kolektif dengan masa kini (Simko \& Simko, 2019). Oleh para kontributor media konvergen, memori kolektif direkonstruksi di masa sekarang, karena ada kebutuhan untuk menjaga perdamaian dan mencegah terjadinya kembali konflik di masa lalu. Memori kolektif di sini merupakan prinsip utama yang mendasari kerja kontributor media konvergen dalam memberitakan keberagaman.

Kedua, memori kolektif yang dimiliki bersama para jurnalis kontributor berita, menjadi dasar di dalam proses seleksi peristiwa yang akan diberitakan, dan cara memberitakannya. Dalam hal ini terlihat bahwa memori kolektif merupakan ingatan-ingatan dan mekanisme persepsi akan apa yang dapat diberitakan dan bagaimana memberitakannya. Dalam hal ini, memorikolektifmenjadi acuan untuk memahami tentang dunia (Golden, 2010), memahami informasi yang aman dan yang berisiko bagi kedamaian masyarakat lokal. Memori kolektif pada tataran ini berada di antara prinsip utama dan dunia kerja kontributor media konvergen di dalam memberitakan isu keberagaman.

Ketiga, ekspresi memori kolektif yang paling terlihat adalah ketika para kontributor ini memilih sudut pandang pemberitaan isu keberagaman, membangun narasi di dalam pemberitaannya, serta melakukan negosiasi dengan redaksi media konvergen di kantor pusat. Hal ini dilatarbelakangi memori kolektif traumatik yang menyebabkan korban peristiwa traumatik termasuk para kontributor berita memaknai keamanan secara spesifik, sebagai realitas yang harus dijaga dengan hati-hati, dan menerima rasa tanggung jawab untuk 


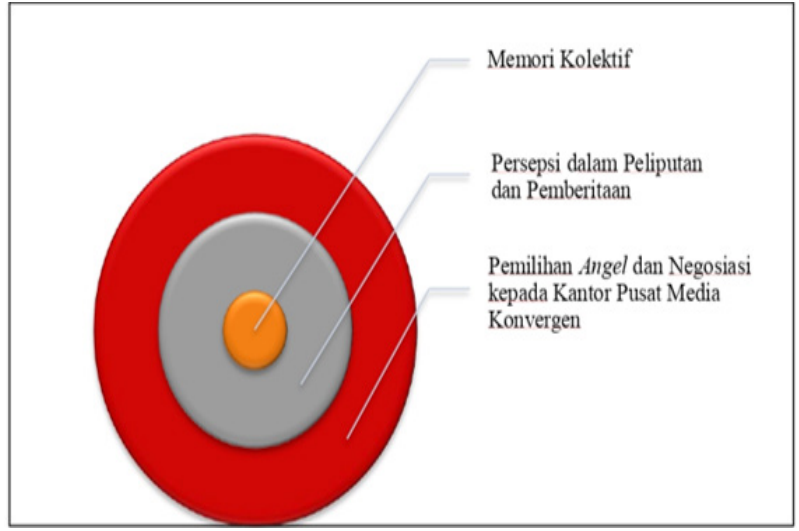

Sumber: Hasil Penelitian, 2019

\section{Gambar 2 Model Lapisan Memori Kolektif dalam Pemberitaan Keberagaman oleh Kontributor Media Konvergen di Wilayah Pasca Konflik.}

menghindari segala bentuk kesalahan yang dapat mengakibatkan keamanan di wilayahnya terganggu (Hirschberger, 2018).

Ketiga lapisan memori kolektif di dalam kerja kontributor media konvergen dari wilayah pasca konflik ketika melakukan pemberitaan keberagaman dapat dirangkum di dalam gambar 2 .

\section{SIMPULAN}

Hasil penelitian memperlihatkan bahwa berdasarkan analisis isi, berita mengenai keberagaman dari wilayah pasca konflik di akun resmi YouTube dari kedua media konvergen yang diteliti pada tahun 2018 jumlahnya sangat rendah. Sementara dari wawancara mendalam, disimpulkan bahwa latar belakang rendahnya pemberitaan keberagaman tersebut adalah kehati-hatian para jurnalis pasca konflik dalam meliput peristiwa keberagaman dikarenakan memori kolektif traumatis akan dampak konflik khususnya pentingnya keamanan wilayah dan tanggung jawab untuk menghindari kesalahan yang dapat mencederai keamanan wilayah yang sudah terbentuk. Kehati-hatian ini menyebabkan kontributor berita dari wilayah pasca konflik menghindari pemberitaan yang dapat berdampak konflik, dalam menetapkan angle, dan dalam memilih narasumber.

Dari simpulan di atas direkomendasikan, agar kantor pusat berita media konvergen melakukan upaya untuk meningkatkan jumlah pemberitaan mengenai keberagaman dari wilayah pasca konflik untuk menghindari disinformasi mengenai realitas keberagamaan dalam konteks kekinian. Pemberitaan keberagaman dari wilayah pasca konflik bersifat problematik bagi para kontributor berita yang memiliki memori kolektif traumatik, hal ini perlu dipahami oleh pihak manajemen media di kantor pusat.

Di samping itu, memori kolektif traumatik yang berujung kehati-hatian para kontributor dari wilayah pasca konflik patut menjadi pembelajaran bagi para kontributor berita dari wilayah lain di dalam memberitakan isu keberagaman agar terhindar dari pengalaman traumatik yang dapat muncul sebagai dampak dari pemberitaan.

\section{DAFTAR PUSTAKA}

Ardianto, E., Komala, L., \& Karlinah, S. (2015). Komunikasi massa suatu pengantar. Bandung: Simbiosa Rekatama Media.

Aviles, G. J. A., Kaltenbrunner, A., \& Meier, K. (2014). Media convergence revisited. Journalism Practice, 8(5).

Baran, S. J. (2012). Pengantar komunikasi massa, melek media dan budaya. Jakarta: Erlangga.

Benedictis, Sara De, Johnson, C., Roberts, J \& Spiby, H. (2019) Quantitative insights into televised birth: a content analysis of One Born Every Minute, Critical Studies in Media Communication, Vol. 36, No. 1, 1-17. https://doi.org/10.1080/15295036.20 18.1516046

Gavilanes, G. R., Mollgaard, A., Tsvetkova, M., \& Yasseri, T. (2017). The memory remains: understanding collective memory in the digital age. Science Advances, 3(4). Doi:10.1126/Sciadv.1602368

Golden, C. (2010). Frayed at the edges: Collective memory and history on the borders of Classic Maya polities. In Ancient Mesoamerica. https://doi.org/10.1017/ S0956536110000246

Grant,A., \& Wilkinson, J. (2009). Understanding media convergence: the state of the field. Journalism \& Mass Communication 
Quarterly.

Hidayat, D. N. (2000). Pers dalam revolusi mei runtuhnya sebuah hegemoni. Jakarta: Gramedia Pustaka Utama.

Hill, D. (1995). Yang alternatif dan yang menyimpang (alternative and deviating) in wartawan independen: sebuah pertanggung jawaban AJI.

Hirschberger, Gilad. (2018). Collective trauma and the social construction of meaning. Frontiers in Psychology. Vol. 9. Article 1441. https://doi.org/10.3389/ fpsyg.2018.01441

Ireton, Posetti, \& Berger. (2018). Journalism, "fake news" \& disinformation [recurso digital]. In UNESCO Series on Journalism Education.

Kompas. (2019). Cara pandang media masih berbeda. Kompas Gramedia.

Laksono, D. D., Bachyul Jb, S., Nugroho, B., Suwarjono, Saputra, R., Pramudya, W., Sudibyo, A., \& Budhi, S. (2012). Mematuhi etik menjaga kebebasan pers. AJI, didukung Yayasan TIFA.

Larrondo, A., Domingo, D., Erdal, I. J., Masip, P., \& Van den Bulck, H. (2016). Opportunities and limitations of newsroom convergence. Journalism Studies. https:// doi.org/10.1080/1461670x.2014.977611

Lindawati, D. S. (2011). Konflik Ambon: kajian terhadap beberapa akar permasalahan dan solusinya. Politica, 2(2).

Loisa, R, Susanto, E. H., \& Junaidi, A. (2019). Online journalist, rapid technology and partial verifications in reporting diversity. Journal of Physics: Conference Series. $\quad$ https://doi.org/10.1088/17426596/1375/1/012032

Loisa, R, Susanto, E. H., Junaidi, A., \& Loekman, F. (2019). Media siber, aparat, dan pemberitaan keberagaman. Jurnal ASPIKOM. https://doi.org/10.24329/ aspikom.v3i6.434

Margianto, H. J., \& Syaefullah, A. (2012). Media online: pembaca, laba, dan etika. Aliansi Jurnalis Independen.

Marta, R. F., \& Rieuwpassa, J. S. (2018). Identifikasi nilai kemajemukan Indonesia sebagai identitas bangsa dalam iklan mixagrip versi keragaman budaya. Jurnal Kajian Komunikasi. http://jurnal.unpad. ac.id/jkk/article/view/15416/8301
McQuail, D. (2011). Teori komunikasi massa mcquail, Edisi 6. Jakarta; Salemba Humanika.

Milles, M. B., Huberman, M. A., \& Saldana, J. (2014). Qualitative data analysis a methods sourcebook Edition 3. In Sage Publications, Inc.

Nurhadi, Z. F. (2017). Teori komunikasi kontemporer. Jakarta: Kencana.

Prastya, N. M. (2017). Media convergence and human resoucres management in sport media newsroom: case study in topskor daily newspaper. Jurnal Komunikasi Ikatan Sarjana Komunikasi Indonesia. https://doi. org/10.25008/jkiski.v2i2.70

Pratopo, W. M., \& Kusajibrata, N. (2018). Konvergensi di ruang redaksi pada kelompok media tempo. Jurnal Studi Komunikasi (Indonesian Journal of Communications Studies). https://doi. org/10.25139/jsk.v2i1.510

Putra, I. E., \& Pitaloka, A. (2012). Psikologi prasangka (sebab, dampak, dan solusi. Jakarta: Ghalia Indonesia.

Qurtuby, s. al. (2016). religious violence and conciliation in Indonesia: christians and muslims in the moluccas. Routledge.

Resmadi, I., \& Yuliar, S. (2014). Kajian difusi inovasi konvergensi media di harian pikiran rakyat. Jurnal Sosioteknologi. https://doi. org/10.5614/sostek.itbj.2014.13.2.5

Rimscha, M. B. von. (2016). Pattern of successful media production. convergence: The International Journal of Research into New Media Technologies., 24(3).

Santosa, B. A. (2017). Peran media massa dalam mencegah konflik. Jurnal Aspikom.

Schulz. D, Afke, V. D. W, Jeroen, W. (2020) The best indycaster project: Analysing and understanding meaningful YouTube content, dialogue and commitment as part of responsible management education, The International Journal of Management Education, Volume 18, Issue 1, 2020, 100335, https://doi. org/10.1016/j.ijme.2019.100335., http:// www.sciencedirect.com/science/article/pii/ S1472811719300667

Setyowati, E. (2015). Profesional Indonesia dalam dimensi budaya di kawasan perbatasan. Kongres Pancasila VII.

Simko, C., \& Simko, C. (2019). Collective 
Memory. In Sociology. https://doi. org/10.1093/obo/9780199756384-0215

Sudibyo, A. (2013). Politik media dan pertarungan wacana. LKiS.

Syam, N. K. (2006). Sistem media massa Indonesia di era reformasi: perspektif teori normatif media massa. Mediator: Jurnal Komunikasi. https://doi.org/10.29313/ mediator.v7i1.1224

Trilling, Damian \& Jeroen G. F. Jonkman (2018) Scaling up content analysis, communication methods and measures, Vol. 12, NOS. 2-3, 158-174 https://doi.org/10.1080/19312458
.2018 .1447655

Vebrynda, R., Maryani, E., \& Abdullah, A. (2017). Konvergensi dalam program net citizen journalism. Jurnal Kajian Komunikasi. http://jurnal.unpad.ac.id/jkk/ article/view/7432/5720

Yin, R. K. (2014). Case study research: design and methods (5th ed.). In Thousand Oaks, CA: SAGE Publications.

Zainuddin, H. M. (1961). Upaya Tarich Atjeh Dan Nusantara. Jakarta: Pustaka Iskandar Muda. 